\title{
POLITITIKK
}

\section{Statsvitenskapelige blindsoner: Iver Neumann i et faglig perspektiv}

\author{
Øivind Bratberg \\ Forstelektor, Institutt for statsvitenskap, UiO
}

\begin{abstract}
Sammendrag
Iver Neumann har vært en eksponent for flerfaglighet på statsvitenskapens vegne. Denne flerfagligheten har vært koblet med en forstålse av politikk som søken etter kollektiv mening og identitet. Begge disse trekkene hos Neumann er gjenkjennelige i europeisk statsvitenskap, kanskje særlig innen studiet av internasjonal politikk. Men i den norske versjonen av faget er de sjeldnere å se. I denne korte artikkelen gir jeg et faghistorisk riss for å plassere Iver Neumann i det norske statsvitenskapelige landskapet. Hovedpersonen selv forstår jeg som en verdensborger som erkjente at det hjemlige faget var for smalt og som søkte nye allianser. Det personlige, nasjonale og internasjonale smelter sammen i Neumanns arbeider, slik populærkultur og politikk også gjør det.
\end{abstract}

Nøkkelord: statsvitenskap • internasjonal politikk • diskursanalyse • sosialantropologi $\cdot$ vitenskapsteori

\section{Innledning}

Iver Neumann er en sjelden fugl i norsk statsvitenskap. I en tid med en stadig mer spesialisert forskningsfront, har Neumann gjennom tre tiår vært en eksponent for flerfaglighet og tverrfaglighet. Og i en tid med mer metodedrevet og ofte maskinorientert statsvitenskap, har Neumanns tilgang vært en ganske annen: ukonvensjonell i sitt datatilfang og fortolkende i sin tilnærming. Han har bidratt til en løpende dialog med antropologi og sosiologi, områdestudier og idéhistorie. Tilsvarende dialog over faggrensene er gjenkjennelig i europeisk statsvitenskap, kanskje særlig innen studiet av

\footnotetext{
^Kontaktinformasjon: Øivind Bratberg, e-post: oivind.bratberg@stv.uio.no

(C)2019 Øivind Bratberg. This is an Open Access article distributed under the terms of the Creative Commons Attribution 4.0 International License (http://creativecommons.org/licenses/by/4.0/), allowing third parties to copy and redistribute the material in any medium or format and to remix, transform, and build upon the material for any purpose, even commercially, provided the original work is properly cited and states its license.

Citation: Øivind Bratberg (2019). Statsvitenskapelige blindsoner: Iver Neumann $i$ et faglig perspektiv. Internasjonal Politikk, 77(2): 158-166. http://dx.doi.org/10.23865/intpol.v77.1588
} 
internasjonal politikk. Men i det norske landskapet er den sjeldnere å se. Et fag som ble meislet ut av historie og statsrett, med sterke innslag fra filosofi og idéhistorie, har i Norge blitt mer selvgående og innadvendt på veien fra 1940-årene til i dag. Neumanns arbeider bryter med denne forståelsen av en stadig tydeligere ramme rundt faget.

Hos Neumann har flerfagligheten også gått sammen med en åpen tilnærming til politikken som studieobjekt. Politikk beskrives ofte som den evige dragkampen om hvordan samfunnet skal innrettes. Denne dragkampen kan lett forstås som brytning mellom rasjonelle aktører med klart definerte egeninteresser. Fagets vitenskapelige pretensjon bygger i så fall på å kartlegge interesser, for så å predikere adferd. Neumanns perspektiv trekker imidlertid i en ganske annen retning og er først og fremst åpent. Snarere enn å lande på en alternativ forklaringsmodell lar han det være gjenstand for nærmere undersøkelse hvor aktører henter sine beveggrunner fra.

En mulig alternativ havn for Neumann ville være i det March og Olsen (2008) definerer som logic of appropriateness (sømmelighetslogikk). Her forklares adferd gjennom lojalitet overfor et fellesskap og dets normer. Neumann beveger seg i det samme landskapet, idet han søker mot ideer og identitet som grunnlaget for politiske preferanser. Det er imidlertid to vesentlige grunner til at Neumann ikke uten videre lener seg på sømmelighetslogikk i sine egne arbeider. For der første er hans søken etter meningsinnhold ikke begrenset til konkrete sosiale institusjoner. Analysene av utenrikspolitikk gir han gjerne forankring gjennom idéhistorisk analyse av en nasjons politiske identitet. For det andre avviker Neumann fra sømmelighetslogikk i sitt eksplisitte fokus på språk - teoretisk og empirisk. Diskursanalyse tillegger språket en rolle ikke bare som vindu inn til aktørers livsverden; språket selv bidrar til å forme, reprodusere og endre kollektive virkelighetsoppfatninger. Teoretisk innebærer det et nært slektskap med humanistiske fag og deres søken mot fortolkning. Metodisk trekkes han mot lingvistikk og idéhistorie, samt mot sosialantropologiens feltarbeid, som blant annet brakte ham til å studere utenrikstjenestens praksiser fra innsiden.

På denne måten demonstrerer politisk analyse à la Neumann det dynamiske eller vilkårlige i måten vi betrakter verden på. Politikk er først og fremst meaning-making; skiftende og ufullendte forsøk på å gi mening og retning til seg selv og sine omgivelser. Men om disse refleksjonene omkring dynamikk og vilkårlighet gjelder det politiske, er det ikke til å unngå at de også har konsekvenser for forskningen og forskeren selv. Også analysen av det politiske er situert, i betydningen formet av verdier, perspektiver og den historiske og sosiale konteksten analysen er frembrakt i. Dersom mening ikke er gitt, følger det med nødvendighet at også tolking av mening er flyktig, skiftende og aldri lovmessig. Dermed er det også forskerens fordømte plikt å reflektere omkring ens eget perspektiv og de verdier de er tuftet på.

I denne korte artikkelen vil jeg gi et faghistorisk riss for å plassere Iver Neumann i det norske statsvitenskapelige landskapet. Hovedpersonen selv forstår jeg som en verdensborger som erkjente at det hjemlige faget var for smalt og som søkte nye allianser; en opprører her hjemme, men langt mindre kontroversiell mot en internasjonal hvelving. 


\section{En kort historie med et meget langt forløp}

Som universitetsfag er statsvitenskap en del av det lange tjuende århundret, til tross for at fagets røtter strekker seg tilbake til antikken. Når det gjaldt nøyaktig hva som var statsvitenskapens egenart og studieområde, trakk ulike nasjonale tradisjoner $\mathrm{i}$ svært forskjellige retninger. Tysk og fransk statsvitenskap bar preg av å ha vokst frem i skyggen av et sterkt offentlig styringssystem. Slik ble det faglige mandatet først og fremst å tolke og gjengi ideene og retningslinjene som lå til grunn for alle statens oppgaver. Statsvitenskap var først og fremst læren om staten, i juridisk og institusjonell forstand, og med noen kulturelle perspektiver på identitet og det nasjonale blandet i. Her fantes det rom mellom jurister på den ene siden og historikere på den andre.

Britisk og amerikansk statsvitenskap var ganske annerledes innrettet. For statsvitere av denne skolen var det ikke noe spesielt høyverdig og seremonielt ved statens institusjoner. De burde forstås som arenaer for interessekamp mellom aktører fra politikken og sivilsamfunnet. Amerikanerne drev det lengst i å ønske seg en presis empirisk vitenskap om denne kappestriden. For britene hang det i mer av en historisk og idéhistorisk tilnærming til statsvitenskap som gjorde at "political studies» ble en vanligere betegnelse enn amerikanernes «political science». Men felles for begge de engelsktalende fagtradisjonene var at de ble utviklet innenfor det liberale demokratiets rammer hvor politikk var fredelig kappestrid med en rimelig grad av medbestemmelse for folket giennom valgte representanter.

$\AA ̊$ analysere og forklare demokratiets interessekamp ble dermed en hovedoppgave for faget. Som den amerikanske statsviteren Harold Lasswell formulerte det i 1936 i boken med samme navn: politikk handler om who gets what, when, how. Statsvitenskapen skulle analysere hvordan. En meny av forskningsspørsmål var ikke så vanskelig å enes om. Hva ønsker velgerne, og hvordan kan de påvirkes? Hvordan er partiene organisert, og hva slags ideer og interesser representerer de? Hvilken betydning har innretningen av politiske institusjoner for beslutningene som tas der? Og hva med byråkratiet som iverksetter politiske beslutninger, kan de også påvirke politikkens innhold?

De amerikanske trendene fikk et solid gjennomslag etter annen verdenskrig, $i$ alle fall i den kulturkretsen Norge var en del av. Slik fikk faget på norsk navnet sitt fra den tyske vitenskapen om staten, men form og innhold passet strengt tatt bedre med den amerikanske vitenskapen om politikk. Her var målet «kunnskap om de sentrale avgjørelsesprosessene i og mellom våre territorialsamfunn, om de formene som disse prosessene inngår i og de innflytelsene som gjør seg gjeldende i dem» (Rokkan, 1972, 29). En slik kartlegging av beslutningsprosesser i og mellom stater ble særlig sentralt for faggrenen vi kjenner som komparativ politikk. Komparativister er, foruten å sammenligne, opptatt av hvem som er politikkens aktører, hvilke krefter som påvirker dem og hvordan beslutninger blir tatt. Men også for de øvrige delene av faget har fokuset på aktører, institusjoner og beslutninger dominert. Mer nedtonet har vært 
den forståelsen av statsvitenskap som ser politikk som søken etter en felles identitet og kollektiv selvforståelse, en tradisjon som Neumann (2011) selv identifiserer med kontinentaleuropeisk statsvitenskap.

\section{Den norske utgaven av faget}

Da statsvitenskap ble etablert i Norge etter andre verdenskrig, var det fra et spinkelt utgangspunkt og helt avhengig av noen bestemte universitetsfolk. Faget var tenkt som verktøy for dem som skulle konsolidere det norske demokratiet og bidra til internasjonalt samarbeid og fred. Statsvitenskapen var tenkt som et orienteringsfag $i$ statens institusjoner og internasjonal folkerett. Sunn styringskunnskap var et opplagt siktemål. Valgforskning kunne for eksempel hjelpe politikere med å komme folkets faktiske ønsker i møte, og innsikt i statens institusjoner ville gi en mer rasjonell og effektiv forvaltning. Den kritiske siden av statsvitenskapen skulle på sin side sørge for refleksjon omkring politikkens innhold så vel som forskerens rolle. I senere utgaver av faget har denne ambisjonen oftest blitt liggende $i$ en underavdeling av politisk teori, snarere enn som maktkritikk i faget som helhet.

Den tidlige utviklingen av norsk statsvitenskap ble påvirket av kontakt med amerikanske forskningsmiljøer. Og her kommer vi ikke utenom å nevne Paul F. Lazarsfeld fra University of Columbia. Han var en østerriksk matematiker som hadde emigrert til USA i de urolige 1930-årene. Til Oslo kom han på besøk høsten 1948. Hva som trengtes, mente han, var systematisk kartlegging av folkemeningen for å styrke dialogen mellom styrende og styrte. Han så for seg et intenst og produktivt samarbeid mellom sosiologer og statsvitere på den ene siden og sosialøkonomene på den andre. Denne koblingen ble det lite av. Hva Lazarsfeld i stedet bidro til, var en nettverksbygging med amerikanske forskere som skulle påvirke både sosiologi og statsvitenskap i Oslo.

Den tydeligste arenaen for denne påvirkningen var valgforskningen. Det norske miljøet passerte en milepæl med den første valgundersøkelsen i 1957. Det var Stein Rokkan som ledet programmet den første tiden på ISFs vegne. Men Rokkan var ikke noen enkelt utskåret valgforsker, og heller ikke noen talsmann for statsvitenskap som styringsvitenskap. Han var særlig opptatt av hvordan ulike sosiale og geografiske grupper var blitt mobilisert og flettet inn i den felles teksturen av nasjonal politikk. Valgforskningen ble dermed et springbrett for det som Rokkan utviklet til å bli en egen avdeling av politisk-historisk sosiologi. Her gjorde han sammenlignende analyse til sin fremgangsmåte. Det som skulle forklares, kunne være kompliserte historiske utviklingsløp på samfunnsnivå. Men forskningen kunne også dreie seg om konkrete partiers geografiske og sosiale grunnlag, og hvordan ulike grupper ble representert i det politiske systemet.

Norsk statsvitenskap har hatt to bærende søyler i komparativ politikk og offentlig politikk og administrasjon. Her finner vi det tydeligste nybrottsarbeidet og de internasjonalt mest kjente statsviterne. Foruten Stein Rokkan er det naturlig å nevne Johan P. Olsen som skulle bli en høvding innen fagfeltet og som trolig er den norske 


\section{Øivind Bratberg}

statsviteren etter Rokkan med et tydeligst fotavtrykk internasjonalt (Thue 1997: 195). Komparativ politikk har trukket i retning teoretisk og metodisk systematikk, ofte (men ikke alltid) med store datasett til rådighet. Offentlig politikk og administrasjon fikk på sin side en vitamininnsprøytning gjennom den første Maktutredningen på 1970-tallet og har siden søkt mot faglig tyngde gjennom et solid lager av teori og en jevn leveranse av byråkrater.

\section{Nye fagdebatter}

Våren 1998 ble forskergruppen bak en ny maktutredning - denne gang som Maktog demokratiutredningen - oppnevnt i statsråd. Nå var konteksten en ganske annen enn ved 1970-tallets øvelse i samme sjanger. Det internasjonale samfunn var først og fremst preget av avslutningen på den kalde krigen og troen på demokrati, fred og frihandel som historiens endemål. Globalisering var en av tidens fremste stikkord. Den norske fredsbyggingsambisjonen skinte på sitt sterkeste. Og i hjemlig politikk var svekkelsen av partiene, fagbevegelsen og Rokkans «korporative kanal», en av antagelsene som maktutredningen ville følge opp. Det var et åpnere samfunn som forskergruppen, ledet av Øyvind Østerud, ga seg i kast med - men også et samfunn med nye utfordringer for folkestyre og kollektiv organisering.

Fem år og rundt 50 bøker og et syttitalls rapporter senere hadde gruppen rimelig klare konklusjoner, og de fleste av dem pekte i negativ retning. Nasjonale institusjoner som tidligere hadde mobilisert og samlet folket, sto ribbet tilbake. Frihandel flyttet makt til internasjonale markedsaktører, og demokratiets kjerne var i skvis mellom marked og juss. Rettsliggjøring sto igjen som et av utredningens helt sentrale begreper. Makten var i drift fra folkevalgte forsamlinger til rettighetsregimer med internasjonalt opphav. New Public Management, konkurranseutsetting og privatisering trakk i samme retning: markedet rår, under rettslig overoppsyn. $\mathrm{Og}$ demokratiet forvitrer.

Bak disse konklusjonene var det uro. To medlemmer trakk seg fra utredningsarbeidet underveis - statsviteren Hege Skjeie og kunsthistorikeren Siri Meyer. Skjeie pekte på at rettsliggjøring tjente kvinnenes sak. Likestilling og frigjøring er dessuten mål som krysser nasjonale grenser, og derfor vil også kampen og rettighetene være det. Meyer fant for sin del at den statsvitenskapelige maktforståelsen var for snever og orientert mot formelle politiske institusjoner, der teorimangfold kunne tilført utredningen noe mer. Aller mest savnet hun perspektivet på makt om mellommenneskelige forhold: hvordan den kommer til uttrykk språklig og visuelt, og hvordan den reproduseres og slipes.

At utredningen var nasjonalt orientert og opptatt av demokratiets formelle institusjoner, var ikke uventet, gitt mandatet. Men konklusjonene og friksjonen som oppsto underveis, kan likevel leses som en oppsummering av statsvitenskapen omkring århundreskiftet. Ingen av de bærende tradisjonene innen faget var spesielt godt egnet til å analysere ustabile og omskiftelige tider. Og de var heller ikke helt i flukt med 
internasjonale fagdebatter. Maktutredningen var kjennetegnet av en fast kjerne i en tid hvor nye faglige perspektiver trakk mot det myke og formbare.

Kontrasten var merkbar til sosiologien, hvor sentrale teoretikere på norsk gjennom hele etterkrigstiden hadde vært opptatt av identitet, språk og ideer. Forskjellene i forhistorie preget også måten konstruktivismen traff disse fagmiljøene på. Blant statsvitere var kringvernet sterkt omkring fagets etablerte forskningsverdier. Konstruktivister ble ofte tolket som at de betvilte at det i det hele tatt "finnes en verden der ute». Faglige nyvinninger internasjonalt - også de som ellers fikk bred tilslutning ble gitt liten plass innen både forskning og undervisning ved de største norske statsvitenskapsmiljøene. Et vesentlig unntak var NUPI, hvor konstruktivistene fant et hjem på norsk jord.

\section{Frifant og frigjører}

Et forsøk på å situere Iver Neumann i norsk statsvitenskap kan gjerne ha Maktutredningen som sitt startsted, ikke minst fordi han selv tok initiativ til en alternativ utredning - Makt- og globaliseringsutredningen - som arbeidet parallelt med den offisielle, men i langt mindre skala. Her sto den porøse grenseflaten mellom nasjonalt og internasjonalt helt sentralt, og arbeidene som ble skrevet under den felles paraplyen var inspirert av idéhistorie, et mykere og bredere maktperspektiv og språk som mediet hvor makt så vel som identitet preges, slipes og reproduseres. Neumanns analyse av bærende begreper i norsk selvforståelse (2001b) var symptomatisk for den nye tid.

Trefningen mellom den store, konvensjonelle og nasjonale utredningen og dens mindre rival hadde en helt konkret forhistorie. I årene fra midt på 1990-tallet sto Iver Neumann sentralt i norsk fagdebatt, med en tildelt - og i noen grad selverklært rolle som annerledestenkende. Debatten foregikk langs minst tre spor. Dels dreide den seg spesifikt om studiet av internasjonal politikk, som Neumann og meningsfeller mente var foreldet i konseptuell, teoretisk og tematisk forstand. Et annet spor handlet om behovet for å (gjen)åpne kontaktflater overfor andre fag. Men det mest fundamentale sporet ledet henimot det teoretiske grunnlaget for samfunnsvitenskapene. Den nye tids ideer hadde komplisert posisjonen mellom naturvitenskap og humaniora som faget tradisjonelt hadde holdt seg med. Åpenbart representerte konstruktivismen noe annet enn den tidløse alliansen med humanistiske fag som tidligere statsvitere kunne støtte seg på. Det var ikke lenger historiefagets måteholdne, situasjonsbaserte forklaringer som var idealet. For forskere av konstruktivistisk legning var oppgaven ofte å tolke aktørers forståelse av seg selv og sine omgivelser, å vise at disse tolkningene (hos forsker som hos aktør) er betingede og deretter undersøke implikasjonene.

Neumanns posisjon i denne fagdebatten ble illustrert gjennom mange empiriske arbeider. For studenter i statsvitenskap var analysene av norsk EU-skepsis som idéhistorisk og diskursivt forankret et konkret eksempel på hva en neumannsk 


\section{Øivind Bratberg}

analyse kunne tilføre og hvorfor den var grunnleggende annerledes. Der den konvensjonelle statsvitenskapens kartla velgere, partistrategier og adferd, stilte Neumann spørsmålet om hvordan vi kom hit, til den særnorske formen for EU-skepsis ved det tjuende århundrets slutt. Svarene fant han i historiske identitetskonstruksjoner som var næret og reprodusert gjennom språk (Neumann 2001b; 2001c; 2009).

Hvordan slike språklig orienterte analyser konkret kunne ta form skisserte Neumann i en håndverksmessig lærebok om diskursanalyse (2001a). Parallelt næret han også en interesse for sosialantropologi som ble ført frem til doktorgrad i 2009. På det tidspunktet hadde fagdebattene falt til ro. Onde tunger vil kanskje hevde at debattanter gikk trett, snarere enn at den nådde noen forløsning. Vitenskapsteori diskuteres lite i norsk statsvitenskap i dag. Innsikter fra konstruktivismen har et visst fotavtrykk i utdanningsløpene, men det er et nett og forsiktig avtrykk. Fagområdet internasjonal politikk er i endring, men først og fremst som en følge av endrede politiske rammevilkår. Slike rammevilkår kan for eksempel peke ut energisikkerhet, klimaforhandlinger eller terrorismebekjempelse, uten at nyorienteringen nødvendigvis er inspirert av noen grunnlagsdebatt.

Neumann kan også leses mot et historisk bakteppe av fagfeltet internasjonale studier. Det var et felt hvor både historikere, jurister, filosofer, sosiologer og hva vi i dag ville kalle områdeeksperter, kunne føle seg hjemme. Idet statsvitenskapen fikk sitt fotfeste som fagdisiplin etter krigen, forsvant internasjonale studier som flerfaglig forskningsfelt fra radaren. Eller, mer presist: det ble trukket i to ulike retninger. På den ene siden ble internasjonal politikk en integrert del av statsvitenskapen, orientert mot utenriks- og sikkerhetspolitikk i konvensjonell forstand. På den andre siden vokste en klart definert fredsforskningstradisjon frem, hvor siktemålet var både å avdekke, forklare og påvirke voldelige konflikter i og mellom samfunn.

Mens fredsforskningsinstituttet PRIO ivaretok den siste varianten av internasjonal politikk, sto NUPI opprinnelig for den første. Forskningen var rettet mot vilkår for norsk utenrikspolitikk, innrammingen var mellomstatlig og de teoretiske perspektivene konvensjonelle. I dag er mye annerledes, og det er i stor grad flerfagligheten og idémangfoldet fra internasjonale studier som har vendt tilbake. Ambisjonen er imidlertid ikke fredsaktivisme, men nytenkning langs et knippe ulike forskningsfronter.

Denne utviklingen er uvegerlig knyttet til Iver Neumanns eget liv og virke. Som faglig entreprenør har han stilt spørsmål ved faglige selvbindinger og bidratt til frigjøring. Prosjektet er forankret i statsvitenskapen, men med et videre utsyn enn "avgjørelsesprosessene i og mellom våre territorialsamfunn" som Rokkan viser til. Det vesentligste i Neumanns bidrag er kanskje evnen til å etablere en alternativ helhet for faget. Det er en helhet tuftet på eklektisk tolkningsarbeid og intern så vel som ekstern tverrfaglighet. Det personlige, nasjonale og internasjonale smelter sammen i Neumanns arbeider, slik populærkultur og politikk også gjør det. Det betyr også en nedbygging av skottene mellom internasjonal politikk, offentlig politikk og administrasjon, komparativ politikk og politisk teori. Dersom politikk 
er søken etter mening, bearbeidelse av kollektive ideer, manifestasjon av identitet, gir det liten mening å koble ulike deler av det politiske fra hverandre $i$ analytisk forstand. Ei heller kan det akademiske studiet av politikk stille seg nøytralt til meningsinnholdet i politikken. Statsviteren er ikke en nøktern observatør, men en kvalifisert tolker og ytrer.

Et slikt perspektiv på faget ligger nær vår samtids forståelse av politikkens natur. Samtidig trekker det i motsatt retning av den økende spesialiseringen som kjennetegner statsvitenskapen som fag. Behovet for en overordnet debatt om statsvitenskap er like aktuelt i dag som i de første etterkrigsårene da faget ble formalisert. I det ordskiftet har Iver Neumanns forskningsbidrag, lærebøker og debattinnlegg en rolle å utøve - $\mathrm{i}$ form av bevisstgjøring om boksene man tenker innenfor og om muligheten til å oppheve dem, helt konkret og for den enkelte student i statsvitenskap.

Deler av denne artikkelen er bearbeidet fra kap. 6 i boken Hva er statsvitenskap? (Universitetsforlaget, 2018), samforfattet med Andreas H. Hvidsten. Jeg skylder en stor takk til Tor Gaute Syrstad samt en anonym fagfelle for konstruktive innspill til teksten.

\section{Om forfatteren}

Øivind Bratberg er førstelektor ved Institutt for statsvitenskap ved Universitetet i Oslo. Han underviser blant annet i kvalitativ metode og er forfatter av Tekstanalyse for samfunnsvitere (2. utgave Cappelen Damm Akademisk, 2017).

\section{Litteraturliste}

Hvidsten, A. H. \& Bratberg, Ø. (2018). Hva er statsvitenskap. Oslo: Universitetsforlaget.

Lasswell, H. (1936). Politics: Who Gets What, When, How. New York, N.J.: McGraw-Hill.

March, J. \& Olsen, J. P. (2008). Logic of Appropriateness. I Goodin, R. E., Moran, M. \& Rein, M. (Red.) The Oxford Handbook of Public Policy. Oxford: Oxford University Press (689-708).

Neumann, I. B. (2011). Tilbake til Durkheim. Staten og antropologien. Oslo: Universitetsforlaget.

Neumann, I. B. (2009). Hvorfor er ikke Norge med i den europeiske union? Internasjonal Politikk 67 (3): 413-425.

Neumann, I. B. (2001a). Mening, materialitet, makt. En innføring $i$ diskursanalyse. Bergen: Fagbokforlaget.

Neumann, I. B. (2001b). Norge - en kritikk. Oslo: Pax.

Neumann, I. B. (2001c). This Little Piggy Stayed at Home: Why Norway is not a Member of the EU. I L. Hansen \& O. Wæver (Red.) European Integration and National Identity: The Challenge of the Nordic States. London: Routledge.

Rokkan, S. (1972). Statsvitenskap - utvikling og status som universitetsfag. Oslo: Universitetsforlaget.

Thue, F. (1997). Statsvitenskapen 50 år. Et kapittel av norsk samfunnsvitenskaps historie. Norsk statsvitenskapelig tidsskrift, 13(3), 187-214. 


\begin{abstract}
English
Iver Neumann has been an inter-disciplinary entrepreneur for political science in Norway. For Neumann, interdisciplinarity has been coupled with an understanding of politics as the search for meaning and identity. These features are well-developed in European political science, particularly within the field of international relations, but they are more rarely encountered in Norway. This brief article provides a sketch of political science as it evolved and matured in its Norwegian incarnation. In situating Iver Neumann within the discipline, I emphasise his international and eclectic orientation. The personal, national and international meet in Neumann's works, as do popular culture and politics.
\end{abstract}

Keywords: political science - international relations - discourse analysis • social anthropology $\cdot$ philosophy of science 